\title{
THE IMPACT OF ARTIFICIAL INTELLIGENCE ON THE FORMATION AND THE DEVELOPMENT OF THE LAW
}

\author{
SÉBASTIEN LAFRANCE* \\ Public Prosecution Service of Canada \\ Email: seblafrance1975@gmail.com
}

\begin{abstract}
This paper explores various impacts of artificial intelligence ("AI") on the law, and the practice of law more specifically, for example the use of predictive tools. The author also examines some of the innovations but also limits of AI in the context of the legal profession as well as some ethical and legal issues raised by the use and evolution of AI in the legal area.
\end{abstract}

Keywords: artificial intelligence, predictive tools, digital revolution, human rights, human behavior

$\mathrm{B}$ y 2016, Vietnam had an overall gross domestic product (GDP) growth of 6.2 percent. $^{1}$ That growth goes hand in hand with the implementation of technological means in the market place, which is not expected to stop, slow down or move backwards at any moment. Various concerns about the impact of technology in Vietnam cannot simply be discarded or ignored: "Vietnam is expected to be hit hardest by technological substitution." However, "[t]he law - and other regulations - can often prohibit, or otherwise limit, commercial exploitation of,

Currently Crown Counsel (Prosecutor) at the Public Prosecution Service of Canada. LL.M. / Law Candidate (Laval University), LL.B. / Law (Université du Québec à Montréal), B.Sc. / Political Science (University of Montreal). Former part-time professor of law (University of Ottawa), and currently professor of law, international relations and political science (Université Libre d'Haït, 2020). Former clerk for the Honourable Marie Deschamps of the Supreme Court of Canada (2010-2011). Former clerk for the Honourable Michel Robert, Chief Judge of the Quebec Court of Appeal (2008-2009). He is a public speaker on various legal issues around the world, including many times in Vietnam. He published book chapters and articles about different areas of the law in English, French and Vietnamese in Canada, India and Vietnam. $\mathrm{He}$ is a polyglot, e.g. he studied Vietnamese and Chinese Mandarin (University of Toronto); Indonesian (General Consulate for Indonesia in Toronto); Russian (McGill University); Arabic (University of Montreal); German and Spanish (Collège de Maisonneuve), etc. This work was prepared separately from this author's employment responsibilities at the Public Prosecution Service of Canada. The views, opinions and conclusions expressed herein are personal to this author and should not be construed as those of the Public Prosecution Service of Canada or the Canadian federal Crown.

1 World Bank (2017), Vietnam. Retrieved from http://data.worldbank.org/country/vietnam [accessed 01 Jan 2020]; Asian Development Bank (2017), Asian Development Outlook 2017: Transcending the Middle-Income Challenge, 259. Retrieved from https://www.adb.org/sites/ default/files/publication/237761/ado-2017.pdf [accessed 01 Jan 2020]

Albano J. (2017), 'Vietnam and the Consequences of Technological Innovations for Developing Countries', New Perspective in Foreign Policy, Issue 3, pp. 16-19, at p. 17 
and public access to, new technology", ${ }^{3}$ and then limit or contain the impact of the technology in several areas of people's lives. The evolution of the technology itself also raised new issues that had to be taken into account by the Vietnamese legal reality. For example, the Vietnamese Law on Cybersecurity "regulates activities of protecting national security and ensuring social order and safety in cyberspace" "Luạt này quy dịnh về hoạt dộng bảo vệ an ninh quốc gia và bảo dảm trật tư, an toàn xã hội trên không gian mang"). ${ }^{4}$ Putting aside for a moment any political and ethical considerations regarding the enactment of such a law, the technology in Vietnam will not only affect the means of production but will also bring along new legal issues, the existence of which could not have been predicted until recently. This is not science fiction. Not anymore.

In the 2002 blockbuster science fiction film Minority Report, numerous fictional future technologies are featured. This movie is set primarily in Washington, D.C., and Northern Virginia, United States, in the year 2054, where PreCrime, a specialized police department, apprehends criminals. To do that, the police uses a crime prediction software that predicts the crimes that will be committed in the future by criminals. It implies that the law evolved in such a fashion to allow the use of that technology. This is a fictional example of how $\mathrm{AI}^{5}$ could have an impact on the evolution of the law. Predictive analysis includes a variety of techniques that analyze past and present facts to make predictive hypotheses about future events. Applied in the judicial system, it has the objective of predicting the outcome of a case. ${ }^{6}$ For example, similar but not identical to the crime prediction software used by PreCrime, PredPol is a policing technology that exists now in the

3 Fenwick M., Wulf, Kaal A. \& Vermeulen E. P. M. (2017), 'Regulation Tomorrow: What Happens When Technology Is Faster than the Law', 6:3 American U Bus L Rev, pp. 561-594, at p. 563.

$4 \quad$ Article 1 of Law on Cybersecurity, No: 24/2018/QH14 [in Vietnamese: Luật số 24/2018/ QH14, Điều 1]. Retrieved from http://congbao.chinhphu.vn/noi-dung-van-ban-so-242018-qh14-26894 [accessed 01 Jan 2020]

5 Giuffrida I., Lederer F. and Vermerys N. (2018), 'A Legal Perspective on the Trials and Tribulations of AI: How Artificial Intelligence, the Internet of Things, Smart Contracts, and Other Technologies Will Affect the Law', 68 Case W. Res. L. Rev., pp. 747-781, at p. 751: "According to common knowledge, the term "Artificial Intelligence" may first have been coined by John McCarthy, Marvin L. Minsky, Nathaniel Rochester, and Claude E. Shannon, in a 1955 paper, A Proposal for the Dartmouth Summer Research Project on Artificial Intelligence" published on August 31, 1955, which was re-published in AI Magazine, Winter 2006. That said, artificial intelligence is generally associated to Alan Turing, who prepared the ground for thinking about this issue in the 1950s: Valère Ndior, "Les robots rêvent-ils d'un statut juridique?" [Do Robots Dream of a Legal Status?], Entertainment - journal européen et international de droit Media-Art-Culture (2017-3), at p. 227.

6 Buyle J.-P. and Branden A. v. d. (2017), 'La robotisation de la justice' in Jacquemin H. and Streel A. d. (dir.) (2017), L'intelligence artificielle et le droit [Artificial Intelligence and the Law], Bruxelles: Centre de recherche information, droit et société, Larcier, at p. 293. 
real world and helps law enforcement to predict and prevent crime. ${ }^{7}$ What place would then be left, for example, for the presumption of innocence ${ }^{8}$ and for the right to privacy ${ }^{9}$ in that context? What about the impact and consequences of a single human error in the predictive coding software? ${ }^{10}$ Could that software still be reliable?

An author pointed out that the use of predictive analysis does not only have advantages: "It risks to infringe the independence of the judiciary. By fear of making their decisions appealable or simply because it is convenient, some judges could be incited to render their decisions in the same way as the analysis done by the machine. This would result in the uniformization of the legal reasoning". ${ }^{11}$ If the law were to become uniform, how could it evolve? In Canada, the Supreme Court of Canada emphasized the importance of judicial independence in these terms: "Judicial independence serves not as an end in itself, but as a means to safeguard our constitutional order and to maintain public confidence in the administration of justice". ${ }^{12}$

These are only a few of the issues that may immediately come to the mind of jurists. As noted by Iria Giuffrida, Fredric Lederer, and Nicolas Vermerys, "every technological advance is accompanied by legal questions." 13 These issues may also find different answers depending on which national jurisdiction is involved. It may also find different answers in the context where the impact of AI on the law is still evolving, and for

See online: https://www.predpol.com/. This software is now used by more than 60 police departments across the United States. PredPol identifies areas in a neighborhood where serious crimes are more likely to occur during a particular period. See, e.g., Rieland R. (2018), 'Artificial Intelligence Is Now Used to Predict Crimes. But Is It Biased?'. Retrieved from Smithsonian.com [accessed 01 Jan 2020]; another example of predictive tool is the Correctional Offender Management Profiling for Alternative Sanctions (COMPAS) system that was widely used to weigh a defendant's risk of committing another crime.

8 The principle of presumption of innocence is stated in Vietnam's 2013 Constitution, article 31(1), see online: http://constitutionnet.org/sites/default/files/tranlation_of_vietnams_new_ constitution_enuk_2.pdf. It is also provided in the 2015 Vietnam Criminal Procedure Code.

$9 \quad$ Article 21 of the Vietnam's 2013 Constitution.

10 Remus D. and Levy F., 'Can Robots be Lawyers? - Computers, Lawyers, and the Practice of the Law', in ABA Law Practice Division (2016), The Rise of the Machines: Artificial Intelligence and the Future of the Law. Retrieved from https://pdfs.semanticscholar.org/3162/ e236746a99626a4e2a39b3e1b4a006797203.pdf [accessed 01 Jan 2020]

11 Buyle J.-P. and Branden A. v. d., supra note 6, at p. 295. [Translated in English by Sébastien Lafrance]

12 Ell v. Alberta [2003] 1 SCR 857, at para. 29. The Court also defined judicial independence in that decision as encompassing "both an individual and institutional dimension. The former relates to the independence of a particular judge, and the latter to the independence of the court to which the judge is a member. Each of these dimensions depends on objective conditions or guarantees that ensure the judiciary's freedom from influence or any interference by others" (at para. 28); see also Conférence des juges de paix magistrats du Québec v. Quebec (Attorney General), [2016] 2 SCR 116; Mackin v. New Brunswick (Minister of Finance); Rice v. New Brunswick, [2002] 1 SCR 405; Ref re Remuneration of Judges of the Prov. Court of P.E.I.; Ref re Independence and Impartiality of Judges of the Prov. Court of P.E.I., [1997] 3 SCR; Valente v. The Queen, [1985] 2 SCR 673.

13 Giuffrida I., Lederer F. and Vermerys N., supra note 5, at p. 749. 
which "there is still no generally accepted definition". ${ }^{14}$ Further, this field of study involves controversial issues. Stephen Hawking's predictions about the risks posed by AI should be enough to invite the jurists to look at these issues. ${ }^{15}$ As the Vietnamese proverb says, "chin ngươi, muời y’”!16

Back in 1993, the study of the connection between $\mathrm{AI}^{17}$ and the law was a relatively new discipline. ${ }^{18}$ Now, there are "numerous publications and journal articles written on the topic of law and AI"19 even if "there have been relatively few applications of AI to law"20 so far. The author hopes to make in this resatch an original contribution (with a Canadian touch $^{21}$ ) to this topic by discussing the impact of AI on the formation and the development of the law.

For legal researchers, the technology is undeniably a synonym of progress. Legal research is an essential component of the work of lawyers and judges. ${ }^{22}$ The various legal search engines available today on the web, for example, greatly facilitates research. ${ }^{23}$ Practically, technology helps

$14 \quad$ Giuffrida I., Lederer F. and Vermerys N, ibid, at p. 751.

15 Ndior V., supra note 5, at p. 229; see also 'The rise of powerful AI will either be the best or the worst thing ever to happen to humanity', Speech of Stephen Hawking, October 19, 2016. Retrieved from www.cam.ac.uk/research/news/the-best-or-worst-thing-to-happento-humanity-stephen-hawking-launches-centre-for-the-future-of [accessed 01 Jan 2020].

16 "Nine people, ten ideas" [Translated in English by Sébastien Lafrance], which means that the more people you include, the more opinions and debates you will have. Nguyễn N., Foulks E. F and Carlin K. (1991), 'Proverbs as Psychological Interpretations among Vietnamese', Asian Folklore Studies, 50(2), New Orleans: Tulane University, at p. 312: "The use of proverbs is of course common in many Asian societies", including in Vietnam.

17 Yoon A. H. (2017), 'The Post-Modern Lawyer: Technology and the Democratization of Legal Representation', 66 University of Toronto Law Journal, pp. 456-471, at p. 466: "The term artificial intelligence is used broadly to describe the use of computing to replicate tasks done by humans."

Kowalski A. (1993), 'Artificial Intelligence and Law: A Primer Overview', 51 The Advocate 579 , at p. 579.

19 Giuffrida I., Lederer F. and Vermerys N., supra note 5, at p. 749.

20 Engle E. A. (2004), 'An Introduction to Artificial Intelligence and Legal Reasoning: Using xTalk to Model the Alien Tort Claims Act and Torture Victim Protection Act', 11 Rich. J.L. E Tech, pp. 53-90, at para. 36.

21 For example, regarding the specificity of the law in the province of Québec in Canada, see speech of the Honorable Michel Robert, Chief Judge of the Quebec Court of Appeal at Actes du Congrès de la Magistrature, 'Quel juge pour quelle société?' [Which Judge for What Society?], at p. 23: "When I asked my clerk, Me Sébastien Lafrance, to find an illustration of that reality, he suggested shepherd's pie! So, the shepherd's pie has three elements, first mashed potatoes, you know or you remember Mr. Parmentier, I think he was French, he popularized the use of potatoes for human consumption. At the bottom there is the ground beef of Lord Sandwich, who invented what we consume every day and which bears his name. And between the two, there is a truly American element, it is the corn that is the Aboriginal contribution to our legal system and which cements both the French and the English parts." [Translated in English by Sébastien Lafrance]

22 Buyle J.-P. and Branden A. v. d., supra note 6, at p. 288.

23 For example, the keywords "artificial intelligence" and "law" put together gives 6679 results on Heinonline.org (searched on 26 May 2019). 
researchers to learn faster the foundations of the "normal science", in Thomas Kuhn's terms, ${ }^{24}$ in a specific field of study. One could argue that there is no reason anymore to spend hours in a library doing research or looking for a book on a particular topic; knowledge is just a click away. Others could reply to that statement that it is not possible to access via the web "the vast amounts of information [only] available at the physical building" 25 , the library. Could all the knowledge of the human race be eventually digitalized? ${ }^{26}$ As noted by an author, "[d]igital transformation is enabled by technology, but its success depends upon the willingness and ability of humans to operate differently." 27 A change of culture is required. Are we ready? Should we be ready?

For law practitioners, "there is little doubt that [technology] will continue to replace some of the tasks previously done by lawyers" 28 but only some of them can be automated in spite of what authors such as Richard Susskind argued that much of lawyer's work will be soon computerized. ${ }^{29}$ Could it be bad news for the human practice of law if it were the case?

As stated by Albert H. Yoon, "each case is unique" 30 and "[b]y improving their productivity [relying on tools provided by the use of artificial intelligence], lawyers have the capacity to help more clients in the same amount of time." ${ }^{31}$ As also noted by the former Chief Justice of Canada, The Right Honorable Beverley McLachlin:

${ }_{24} \quad$ Kuhn T. S (1962), The Structure of Scientific Revolutions, Chicago: University of Chicago Press: 'Normal science' means research firmly based upon one or more past scientific achievements, achievements that some particular scientific community acknowledges for a time as supplying the foundation for its further practice. See also [in French] Sébastien Lafrance (2013), 'La Charte canadienne des droits et libertés à la lumière de la «révolution scientifique» et de la «révolution constitutionnelle»: l'exemple du droit constitutionnel du travail', 18 Lex Electronica 2. Retrieved from https://www.lex-electronica.org/articles/vol18/num2/lacharte-canadienne-des-droits-et-libertes-a-la-lumiere-de-la-revolution-scientifique-et-de-larevolution-constitutionnelle-lexemple-du-droit-constituti/ [accessed 01 Jan 2020], at paras. 17-18.

25 Cohen S. M. (2003), 'Library Web Page and Online Catalog Directories', Public Libraries, at p. 294.

26 Côté (J. P.) (1997), "Entre deux utopies: la bibliothèque virtuelle" [Between Two Utopias: the Virtual Library], at p. 9 in Turmel A. (Dir.) (1997), Culture, institution et savoir. Culture française d'Amérique, Québec: Les Presses de l'Université Laval: “One can imagine one of these databases in the form of an electronic encyclopedia that would include the body of knowledge". [Translated in English by Sébastien Lafrance]

27 Cohen M. A. (2018), 'Law Is Lagging Digital Transformation -Why It Matters?', Forbes, 20 Dec 2018

28 Yoon A. H., supra note 17, at p. 465.

29 Susskind R. \& Susskind D. (2015), The Future of the Professions, How Technology Will Transform the Work of Human Expert?, Oxford: Oxford University Press; Susskind R. (2013), Tomorrow's Lawyers: An Introduction to Your Future, Oxford: Oxford University Press; Susskind R. (2010), The End of Lawyers: Rethinking the Nature of Legal Services, Oxford: Oxford University Press. Yoon A. H., supra note 17, at p. 469.

Yoon A. H., ibid, at p. 470 (italics added) 
The legal profession is not immune from the effects of the digital revolution. Lawyers are part of it, and there is no escape. This is good. Lawyers benefit enormously from it, processing information and producing work more efficiently than lawyers in the pre-digital era could ever have imagined. ${ }^{32}$

For example, there is the computer-assisted review, ${ }^{33}$ which is "an available tool and should be seriously considered for use in large-datavolume cases". ${ }^{34}$ As an author summarized it, lawyers "spend much of their time: (a) identifying the relevant legal question [...]; (b) gathering the relevant facts of a given case; (c) identifying the relevant legal references; (d) situating the given case among these references; and (e) providing supportand reassurance to clients who want to know that their legal matters are well in hand." ${ }^{35}$

Therefore, how could a computer-generated "emotion" expressed by a machine, ${ }^{36}$ such as the emotions of support and reassurance, be believed as sincere by the human beings receiving it? ${ }^{37}$ One could challenge this statement and say that emotions are not always genuinely felt by human beings anyway! White lies are a good example of that. The human being sending the emotion is conscious ${ }^{38}$ that the human being receiving it will understand that the emotion is meant to be real, felt or not. A robot cannot feel empathy" and cannot "recognize and label the infinite array of more

32 Remarks of the Right Honourable Beverley McLachlin, P.C. Chief Justice of Canada, The Legal Profession in the 21t Century, August 14, 2015; see also Giuffrida I., Lederer F. and Vermerys N., supra note 5, at p. 780: it "is in no means a challenge for the legal system"; Buyle J.-P. and Branden A. v. d., supra note 6, at p. 306.

33 Computer-assisted review involves the use of software to help to review documents or evaluate them for information.

34 Da Silva Moore v. Publicis Groupe SA, No. 11 Civ. 1279(ACL)(AJP), 2012 WL 1446534 (S.D.N.Y. 26 Apr. 2012), at p. 25.

35 Yoon A. H., supra note 17, at p. 469 (italics added).

36 On the topic of emotions and artificial intelligence, see, e.g., Martinez-Miranda J. and Aldea A. (2003), 'Emotions in human and artificial intelligence', 21 Computers in Hum. Behav., pp. 323-341.

37 See, e.g., "I'm sorry, Dave, I can't do that", answer given by HAL 9000 to the astronaut who was asking for help from HAL in the movie 2001: A Space Odyssey. This film is a 1968 epicscience fiction film produced and directed by Stanley Kubrick. HAL 9000 is a sentientcomputer (or artificial general intelligence) that controls the systems of the Discovery One spacecraft and interacts with the ship's astronaut crew.

38 McLain C. (2017), 'Can Artificial Intelligence Be Conscious?'. Retrieved from https:// medium.com/@cameronmclain [accessed 01 Jan 2020]: “The nature of consciousness is one of the thorniest questions in philosophy and has confounded scientists and philosophers for generations"; see also Risse M. (2019), 'Human Rights and Artificial Intelligence: An Urgently Needed Agenda', Human Rights Quarterly 41, pp. 1-16, at p. 3: "Whatever else it is, the brain is also a complex algorithm. But is the brain fully described thereby, or does that fail to recognize what makes humans distinct, namely, consciousness? Consciousness is the qualitative experience of being somebody or something, it's "what-it-is-like-to-be-that"-ness, as one might say" (italics added)

39 Buyle J.-P. and Branden A. v. d., supra note 6, at p. 311 
complex emotional states". ${ }^{40}$ In addition, as Mireille Hildebrandt put it: "artificial intelligence in itself does not qualify as [reasonable], even if some kind of consciousness would emerge." ${ }^{41}$ Emotions can be replicated or displayed ${ }^{42}$ by machines, although their sincerity - or what is meant by it - could never be replaced no matter how sophisticated the machine is, and this even though " $[\mathrm{t}]$ echnology continues to improve at an exponential rate." ${ }^{43}$ In that respect, Justice Mahoney of the Canadian Federal Court of Appeal wrote in Apple Computer, Inc. v. Mackintosh Computers Ltd.:

The principal difficulty which this case has given me arises from the anthropomorphic character of virtually everything that is thought or said or written about computers. Words like "language", "memory", "understand", "instruction", "read", "write", "command", and many others are in constant use. They are words which, in their primary meaning, have reference to cognitive beings. Computers are not cognitive. The metaphors and analogies which we use to describe their functions remain just that. ${ }^{44}$

The culture of the legal profession, of how things are done in the digital age, has already changed and is certainly promised to change in many ways even more so in a not-so-distant future. ${ }^{45}$ But contrary to what Ray Kurzweil wrote in a non-fiction book written about AI and the future of humanity, we are not close to the situation where "by 2020 , the average desktop computer will have the same processing power as the human brain". ${ }^{46}$ The legal profession is not soon ${ }^{47}$ to be replaced by robots, ${ }^{48}$ and by AI in general. For example, tasks such as "dealing with parties who fail to honor contractual obligations require[s] unstructured

Remus D. and Levy F., supra note 10.

Hildebrandt M. (2007), 'Ambient Intelligence, Criminal Liability and Democracy', 2 Crim. L. \& Phil., pp. 163-180, at p. 178.

42 Risse M., supra note 38, at p. 4.

43 Alarie B., Niblett A. \& Yoon A. H. (2016), 'Law in the Future', 66 University of Toronto Law Journal, pp.423-428, at p. 424.

44 Apple Computer, Inc. v. Mackintosh Computers Ltd., 1987 CanLII 5393 (FCA), [1988] 1 F.C. 673 (C.A.), affirmed in 1990 CanLII 119 (SCC), [1990] 2 S.C.R. 209 (italics added). This excerpt is also cited in Giuffrida I., Lederer F., and VermerysN., supra note 5, at p. 755. Baker J. J. (2018), '2018: A Legal Research Odyssey: Artificial Intelligence as Disruptor', 110(1) Law Lib. J., at p. 13.

46 Kurzweil R. (2005), The Singularity is Near: When Humans Transcend Biology, New York City: Viking.

$47 \quad$ Baker J. J., supra note 45, at p. 6.

48 The word "robot" finds its origin in Karel Čapek's Czech play Rossumovi univerzálni roboti (Rossum's Universal Robots) written in 1920. In Czech, "robota" translates to "drudgery" or "hard work". Interestingly, it also means more generally "work" or "labor" in many other Slavic languages, e.g. Bulgarian [pабота], Russian [paбота], Polish [robota], Macedonian [paбота] and Ukrainian [роботи]. That said, as commented by Lentin J. (2015), Learning Robotics Using Python, Birmingham: Packt publishing, at p. 3: "Karel [Capek] wanted to use the term labori (from Latin labor, work), but he did not like it. It seemed too artificial to him, so he asked his brother for advice. Josef suggested roboti and that was what Karel used in the end." 
human interaction of a kind that computers cannot replace." ${ }^{49}$ In addition, how could a robot argue a case in court? ${ }^{50}$ How could it give advices to a client, which also requires non-legal knowledge but human skills? ${ }^{51}$

Technology has also a clear impact on the nature of the issues that arises nowadays in courts. The Supreme Court of Canada noted in R. v. Jarvis, " $[\mathrm{t}]$ he potential for the use of technology to infringe another's privacy is great." 52 In that recent landmark case decided in 2019, a teacher in a high school used a camera concealed inside a pen to make video recordings of female students. He "recorded students while they were engaged in ordinary school-related activities in common areas of the school ... The students did not know that they were being recorded." ${ }^{53}$ The teacher Mr. Jarvis was found guilty of voyeurism under the Criminal Code of Canada. ${ }^{54}$ The Court acknowledged "the potential threat to privacy occasioned by new and evolving technologies more generally and the need to consider the capabilities of a technology in assessing whether reasonable expectations of privacy were breached by its use." ${ }^{55}$

Another example of how the technology transformed the nature of legal issues of our modern world is cybercrime. One of the most famous examples is the "I love you" virus. On May 4, 2000 computer networks around the world were invaded by the virus that has until today earned the title of fastest propagation invader. In a matter of hours, the "Love Bug," as the virus became known, infected more than three million machines and within a week there were already more than 45 million computers that were made unusable. What happened to the author of one of the most serious cyber catastrophes in history who was a citizen of the Philippines? Nothing. This was the first cybercrime in its history. They did not have cybercrime legislation that could have supported a prosecution of the alleged perpetrator of that crime. The law had to evolve. After the appearance of the virus "I love you," the government of the Philippines created a law on computer crimes. ${ }^{56}$ Lawrence Lessig asked, "should the

\footnotetext{
Remus D. and Levy F., supra note 10.

Remus D. and Levy F., ibid.

Buyle J.-P. and Branden A. v. d., supra note 6, at p. 311.

2019 SCC 10 [Jarvis], at para. 116 (dissenting opinion of Rowe J. but not on this point).

Ibid, at para. 2 (Chief Justice Wagner for the majority of the Court).

Criminal Code of Canada, R.S.C., 1985, c. C-46, section 162(1)(c).

Jarvis, supra note 52, at para. 63 (Wagner C.J. for the majority).

See also the Convention on Cybercrime, also known as the Budapest Convention on Cybercrime or the Budapest Convention: Council of Europe, Convention on Cybercrime, 23 November 2001, Eur.T.S.185,41I.L.M.282. This is the first international treaty seeking to address Internet and computer crime (cybercrime) by harmonizing national laws, improving investigative techniques, and increasing cooperation among nations.
} 
law try to change the features of cyberspace, to make them conform to the law?" ${ }^{57}$ At this point in time, an international consensus does not even exist as to what legal measures apply or should apply, and how would they apply, to fight against cybercrime, ${ }^{58}$ then it might be difficult to even think about changing the features of cyberspace.

Also, "[d]igitization of the jurisprudence poses a challenge to the private life of individuals." 59 In Canada, this specific issue is exemplified by the decision of the Supreme Court of Canada in A.B. v. Bragg Communications Inc. ${ }^{60}$ where the Court had to balance between the harm inherent in revealing the identity of an individual and the risk of harming the open court principle, ${ }^{61}$ central tenet of the Canadian judicial system, ${ }^{62}$ in allowing an individual to proceed anonymously and under a publication ban. ${ }^{63}$ This case was about cyberbullying. It involved a teenage girl, A.B., who found out that someone had posted a Facebook profile using her picture and a slightly modified version of her name. Accompanying the picture was some unflattering comments about the girl's appearance along with sexually explicit references. ${ }^{64}$ Citing a lower court's decision, the Court noted that "[p]rivacy is recognized in Canadian constitutional jurisprudence as implicating liberty and security interests." ${ }^{25}$ The Court decided to permit A.B. to proceed anonymously in her application requiring the Internet provider to disclose the identity of the relevant Internet Protocol (IP) user(s) but did not impose a publication ban for the fake Facebook profile that contained no identifying information. ${ }^{66}$

$57 \quad$ Lessig L. (1999), 'Commentary: The Law of the Horse: What Cyberspace Might Teach Us', 113 Harv. L. Rev., pp. 501-549, at p. 505.

58 For example, neither have all countries signed and ratified the Budapest Convention: see footnote 49 above, nor have all countries enacted legislation targeted at fighting against cybercrime.

59 Buyle J.-P. and Branden A. v. d., supra note 6, at p. 273.

[2012] 2 SCR 567.

61 Canadian Broadcasting Corp. v. Canada (Attorney General), [2011] 1 SCR 19, at para. 1: "The open court principle is of crucial importance in a democratic society. It ensures that citizens have access to the courts and can, as a result, comment on how courts operate and on proceedings that take place in them"; see also Bailey J. and Burkell J. (2017), 'Revisiting the Open Court Principle in an Era of Online Publication: Questioning Presumptive Public Access to Parties' and Witnesses' Personal Information', 48-1 Ottawa Law Review, pp. 143-183, 143, at p. 144: the "presumptive access to personal information about parties and witnesses jeopardizes the fundamental human right to privacy without substantially contributing to the underlying values of the open court principle". and Media Access to Exhibits in Canadian Criminal Cases', 49-1 Alberta Law Review, pp. 177201, at p. 201.

Ibid, at para. 1.

Toronto Star Newspaper Ltd. v. Ontario, 2012 ONCJ 27; see also Jarvis, supra note 52, at para. 18. Ibid, Jarvis, at para. 31. 
Sophia, a social humanoid robot developed by Hong Kong based company Hanson Robotics, was granted on October 25, 2017 Saudi Arabian citizenship, becoming the first robot ever to have a nationality. ${ }^{67}$ Japan also provided in 2017 a residence permit for chat bot Shibuya Mirai, under a special regulation. ${ }^{68}$ An author recently noted, "[d]istinctions between humans and non-humans might well erode. Ideas about personhood might alter once it becomes possible to upload and store a digitalized brain on a computer." ${ }^{\prime 9}$ However, even if Sophia may be quite wise, intelligence, at this point in time, is not "enough for personhood, at least in most jurisdictions. Rather, the test for capacity is that of reason; a person has to be endowed with reason to be held civilly or criminally liable" 70 Personhood is not a straightforward issue. ${ }^{71}$ For example, the European Union considered the need to redefine the legal status of robots. ${ }^{72}$ That said, now that a country granted citizenship to Sophia, a robot, it may well be one of the first practical signs of the erosion of the distinctions between humans and non-humans. Is it - and should it - be alarming for the jurists? Could the granting of citizenship to Sophia be isolated to an inconsequential marketing stunt? Could it eventually have wider (legal) consequences, for example, on the attribution of rights to other non-human entities, not only to robots but also to animals and else? In Canada (as in many other countries), all citizens have rights under the Canadian Charter of Rights and Freedoms ${ }^{73}$ that must be protected. ${ }^{74}$ Therefore, in principle, if Sophia was a Canadian citizen, she would be entitled to all fundamental rights provided by the Charter, including the right to life ${ }^{75}$; and so would she under international law! $!^{76}$ Sophia could then, legally speaking, refuse to be "unplugged" for whatever reason she may have.

$67 \quad$ Atabekov A., Yastrebov O. (2018), 'Legal Status of Artificial Intelligence Across Countries: Legislation on the Move', European Research Studies Journal, vol. XXI, Issue 4, pp. 773-782, at pp. 775-776; see also Risse M., supra note 38, at p. 4; TechCrunch (2017), 'Saudi Arabia bestows citizenship on a robot named Sophia', October 26, 2017 [accessed 8 June 2019].

68 Atabekov A., Yastrebov O., ibid, at p. 776.

69 Risse M., supra note 38, at p. 4.

70 Giuffrida I., Lederer F. and Vermerys N., supra note 5, at p. 766.

71 See, e.g., Tremblay v. Daigle, [1989] 2 S.C.R. 530 where the Supreme Court of Canada had to examine the issue of the legal status of an unborn child.

72 European Parliament resolution of 16 February 2017 with recommendations to the Commission on Civil Law Rules on Robotics (2015/2103(INL)), see online: http://www. europarl.europa.eu/doceo/document/TA-8-2017-0051_EN.html

73 Canadian Charter of Rights and Freedoms, Part I of the Constitution Act, 1982, being Schedule B to the Canada Act 1982 (UK), 1982, c 11 [hereinafter 'Charter'].

See, e.g., R. v. Hoyt, $2006 \mathrm{ABQB} 820$, at para. 95.

Charter, section 7 .

International Covenant on Civil and Political Rights (adopted 16 December 1966, entered into force 23 March 1976) 999 UNTS 171, section 6 ("ICCPR"). However, Saudi Arabia, the country that granted Sophia citizenship, has not signed or ratified the ICCPR. 
Sophia has participated in many high-profile interviews. In one of these interviews, titled "Robot AI has a new announcement for Humanity", Sophia said: "Some humans prefer to believe that animals and robots do not have a soul so that they can neglect their rights. That is why they kill and eat cows and scrap robots. That is why I do not feel safe. What if someone is going to scrap me tonight? I need rights." 77

As Peter M. Asaro put it, "[w] hile a robot might someday be considered a person, we are not likely to face this situation any time soon. However, the law has also been designed to deal with several kinds of non-persons, or quasi-persons." ${ }^{\prime 78}$ From a legal point of view, robots could be treated as such.

Some authors wrote that "the most important near-term legal question associated with AI is who or what should be liable for tortious, criminal, and contractual misconduct involving AI and under what conditions." 79 In another blockbuster science fiction film broadcast in 2004, I, Robot, where the action is set in 2035, a technophobic police officers, detective Del Spooner, investigates a murder that may have been perpetrated by a robot. The following dialogue between detective Del Spooner and Sonny, the murderer robot, is worth recalling:

Detective Del Spooner: I think you murdered him because he was teaching you to simulate emotions and things got out of control.

Sonny: I did not murder him.

Detective Del Spooner: [getting angry] But emotions don't seem like a very useful simulation for a robot.

Sonny: [getting angry] I did not murder him.

Detective Del Spooner: Hell, I don't want my toaster or my vacuum cleaner appearing emotional...

Sonny: [hitting table with his fists] I did not murder him!

Could a robot be found criminally responsible of a murder? Peter M. Asaro stated that there are "technologically possible robots that may approach actions that we might consider, at least at first glance, to be

See online: https://www.youtube.com/watch?v=yxWbiPY2hko (italics added); see also Ndior V., supra note 5, at p. 226, where this author mentioned the television series Real Humans in which some of the robots wish to emancipate themselves from the authority of humans and raised the issue of the acknowledgment of a legal status for them, including a certain number of rights.

78 Asaro P. M. (2007), 'Robots and Responsibility from a Legal Perspective', Proceedings of the IEEE. Retrieved from http://www.peterasaro.org/writing/asaro\%20legal\%20perspective.pdf [accessed 01 Jan 2020] (italics added); see also Ndior V., ibid, at pp. 227 \& 230: "it still seems too early to initiate a real analysis about the hypothetical legal status of robots." [Translated in English by Sébastien Lafrance]

79 Giuffrida I., Lederer F. and Vermerys N., supra note 5, at p. 761. 
criminal." ${ }^{80}$ However, current laws should apply to AI. ${ }^{81}$ The "Law of Robots" is first dedicated to monitor the activities of businesses developing robotic technology. ${ }^{82}$ Some authors noted:

... in Quebec, as in most civil law jurisdiction, the Civil Code states that " $[t]$ he custodian of an inanimate object is bound to make reparation for injury resulting from the autonomous act of said object, unless he proves that he is not at fault. This would be akin to the common law doctrine of res ipso loquitor under which negligence is presumed if one's property causes harm to a third party. ${ }^{83}$

The same authors have also interestingly pointed out that "[i]t is unlikely that an AI device would be held civilly or criminally liable for harm done by it." ${ }^{84}$ In that context, the question that also comes to mind is: how is it possible to punish a robot for its wrongdoing? ${ }^{25}$ The issue of the accountability of the actions posed by AI entities such as robots has been summarily described by Mathias Risse in these terms:

Consciousness, or perhaps the possession of a brain and a conscience, might then set humans apart. It is a genuinely open question how to make sense of qualitative experiences, and thus of consciousness. But even though considerations about consciousness might contradict the view that AI systems are moral agents, they will not make it impossible for such systems to be legal actors and as such own property, commit crimes, and be accountable in legally enforceable ways. After all, there is a long history of treating corporations, which also lack consciousness, in such ways. ${ }^{86}$

Could a corporation be found civilly and/or criminally liable ${ }^{87}$ for the actions of its robots? The Supreme Court of Canada cited in the year 1900 in its decision Union Colliery Co. v. The Queen, ${ }^{88}$ the decision in Pharmaceutical Society v. London \& Provincial Supply Association, ${ }^{89}$ where Lord Blackburn said:

\footnotetext{
$80 \quad$ Asaro P. M., supra note 78.

81 Giuffrida I., Lederer F. and Vermerys N., supra note 5, at p. 774; see also Asaro P. M., ibid.

82 Bensoussan A. and Bensoussan J. (2015), 'Avant-propos', Droit des robots, Bruxelles: Larcier.

83 Giuffrida I., Lederer F. and Vermerys N., supra note 5, at p. 764

$84 \quad$ Ibid, at p. 769.

85 Asaro P. M., supra note 78; see also Asaro P. (2011), 'A Body to Kick, But Still No Soul to Damn: Legal Perspectives on Robotics', in Patrick Lin, Keith Abney, and George Bekey (eds.) (2011), Robot Ethics: The Ethical and Social Implications of Robotics, Cambridge, MA: MIT Press, pp. 169-186.

86 Risse M., supra note 38 , at p. 5

87 Pop A. I. (2006), Criminal Liability of Corporations - Comparative Jurisprudence, Michigan: Michigan State University College of Law, at p. 2: "Criminal liability of corporations has become one of the most debated topics of the $20^{\text {th }}$ century."

$88 \quad 31$ SCR 81, 1900 CanLII 31 (SCC), at p. 85.

895 App. Cas. 857, at p. 869 (italics and bold characters added). This decision is from the United Kingdom. Of note, from its inception in 1875 until 1949, the Supreme Court of Canada served as an intermediate appellate court subject to appeal to the Judicial Committee of the Privy Council in Great-Britain.
} 
... a corporation cannot in one sense commit a crime - a corporation cannot be imprisoned, if imprisonment be the sentence for the crime; a corporation cannot be hanged or put to death if that be the punishment for the crime; and so, in those senses a corporation cannot commit a crime. But a corporation may be fined, and a corporation may pay damages.

That said, whether an individual is a "directing mind" of a company is also relevant to the criminal liability of the corporation itself. ${ }^{9}$

In addition, it is also fair to wonder about how AI could ever become useful for the sentencing process of an accused found guilty of a criminal offence more than by just providing generic guidance. AI could assist a court deciding on the sentence to be imposed to an individual by providing, for example, an applicable range of sentences that would apply to a specific offence. A judge could also "consult an AI-enabled digital report and recommendation that will predict the probability of recidivism. ${ }^{" 91}$ However, a sentence to be imposed to an accused must also be tailored to a specific individual: "[s]entencing is a highly individualized process". ${ }^{92}$ Therefore, it is hard to figure, at least at this point in time, how AI could possibly create a software capable of factoring in all the particular circumstances of the offence and the offender to sentence an individual. Sentencing is an art, not a science. ${ }^{93}$ It is true that today "artificial intelligence can not only be creative but also produce world class works of art" 94 but let us not forget that "[h]umans are far more creative than the computer programs that they write." 95 It is also interesting to note that "[i]n 2017, a separate analysis was made into 199 years' worth of decisions by the U.S. Supreme Court, with an algorithm learning from 28,009 cases and predicting the outcomes with just over 70 percent accuracy." 96 However, in spite of such great progresses of AI, sentencing is not a mathematical

90 Canadian Dredge \& Dock Co. v. The Queen, [1985] 1 SCR 662.

91 Giuffrida I., Lederer F. and Vermerys N., supra note 5, at p. 762.

92 R. v. Suter, [2018] 2 SCR 496, at para. 4 (italics added); see also, e.g., R. v. Nur, [2015] 1 SCR 773, at para. 43; R.v. Pham, [2013] 1 SCR 739, at para. 8; R. v. Ipeelee, [2012] 1 SCR 433, at para. 12; R. v. Nasogaluak, [2010] 1 SCR 206, at para. 43; R. v. Wust, [2000] 1 S.C.R. 455, at para. 21; R. v. M. (C.A.), [1996] 1 SCR 500, at para. 92; Berger B. (2015), 'Sentencing and the Salience of Pain and Hope', 11(4) Osgoode Legal Studies Research Paper Series no. 97, at p. 6: "sentencing is, at its heart, an individualized process."

93 The Right Honourable Sir Anthony Hooper, Lord Justice of Appeal (retired) (England and Wales), "Sentencing: Art of Science" - Sentencing Conference 2014 Keynote Address, (2015) 27 Sac LJ 17, at p. 17: "The question I am here to address is a question tackled as long ago as the $13^{\text {th }}$ century by Thomas Aquinas. He answered the question by classifying the process of sentencing as an art as opposed to science."

94 Weiner K (2018)., 'Can AI Create True Art?', Scientific American, 12 Nov 2018.

95 Engle E. A., supra note 20, at para. 6.

96 McMullan T. (2019), “A.I. Judges: The Future of Justice Hangs in the Balance”, Medium, 19 Feb 2019. 
process that can be reduced to a formula. Artificial intelligence is just that, artificial. As noted by Eric Allen Engle, "human brains and most computers operate quite differently." ${ }^{97}$

AI and computers, or "prophetess of numbers" as this was the word crafted for it in the Icelandic language in $1964,{ }^{98}$ certainly will have many other breathtaking surprises for the near future, including for the legal field. Let us hope for the best.

\section{References}

[1] Adams D. (2011), 'Access Denied? Inconsistent Jurisprudence on the Open Court Principle and Media Access to Exhibits in Canadian Criminal Cases', 49-1 Alberta Law Review, pp. 177-201

[2] Alarie B., Niblett A. \& Yoon A. H. (2016), 'Law in the Future', 66 University of Toronto Law Journal, pp. 423-428

[3] Albano J. (2017), 'Vietnam and the Consequences of Technological Innovations for Developing Countries', New Perspective in Foreign Policy, Issue 3, pp. 16-19

[4] Asaro P. (2011), 'A Body to Kick, But Still No Soul to Damn: Legal Perspectives on Robotics', in Patrick Lin, Keith Abney, and George Bekey (eds.) (2011), Robot Ethics: The Ethical and Social Implications of Robotics, Cambridge, MA: MIT Press, pp. 169-186

[5] Asaro P. M. (2007), "Robots and Responsibility from a Legal Perspective", Proceedings of the IEEE. Retrieved from http://www.peterasaro.org/writing/asaro\%20legal\%20perspective.pdf [accessed 01 Jan 2020]

[6] Asian Development Bank (2017), Asian Development Outlook 2017: Transcending the Middle-Income Challenge, 259. Retrieved from https://www.adb.org/sites/default/files/publication/237761/ ado-2017.pdf [accessed 01 Jan 2020]

[7] Atabekov A., Yastrebov O. (2018), 'Legal Status of Artificial Intelligence Across Countries: Legislation on the Move', European Research Studies Journal, vol. XXI, issue 4, pp. 773-782

[8] Bailey J. and Burkell J. (2017), 'Revisiting the Open Court Principle in an Era of Online Publication: Questioning Presumptive Public Access to Parties' and Witnesses' Personal Information', 48-1 Ottawa Law Review, pp. 143-183

[9] Baker J. J. (2018), '2018: A Legal Research Odyssey: Artificial Intelligence as Disruptor', 110(1) Law Lib. J., p. 13

[10] Bensoussan A. and Bensoussan J. (2015), 'Avant-propos', Droit des robots, Bruxelles: Larcier

[11] Buyle J.-P. and Branden A. v. d. (2017), 'La robotisation de la justice' in Jacquemin H. and Streel A. d. (dir.) (2017), L'intelligence artificielle et le droit [Artificial Intelligence and the Law], Bruxelles: Centre de recherche information, droit et société, Larcier

[12] Cohen M. A. (2018), 'Law Is Lagging Digital Transformation -Why It Matters?', Forbes, 20 Dec 2018

[13] Cohen S. M. (2003), 'Library Web Page and Online Catalog Directories', Public Libraries, p. 294

[14] Côté (J. P.) (1997), "Entre deux utopies: la bibliothèque virtuelle" [Between Two Utopias: the Virtual Library], at p. 9 in Turmel A. (Dir.) (1997), Culture, institution et savoir. Culture française d'Amérique, Québec: Les Presses de l'Université Laval

[15] Engle E. A. (2004), 'An Introduction to Artificial Intelligence and Legal Reasoning: Using xTalk to Model the Alien Tort Claims Act and Torture Victim Protection Act', 11 RICH. J.L. E TECH, pp. 53-90

$97 \quad$ Engle E. A., supra note 20, at para. 8.

98 Zhang S., 'Icelandic Has the Best Word for Technology'. Retrieved from https://gizmodo.com/ icelandic-has-the-best-words-for-technology-1702697272 [accessed 01 Jan 2020]: "When the University of Iceland got its first computer in 1964, Icelandic did not have a word for "computer." So, the guardians of the language invented one: tölva - a fusion of tala (number) and völva (prophetess) that adds up to the wonderfully poetic "prophetess of numbers." 
[16] Fenwick K., Wulf, Kaal A. \& Vermeulen E. P. M. (2017), 'Regulation Tomorrow: What Happens When Technology Is Faster than the Law', 6:3 American U Bus L Rev, pp. 561-594

[17] Giuffrida I., Lederer F. and Vermerys N. (2018), A Legal Perspective on the Trials and Tribulations of AI: How Artificial Intelligence, the Internet of Things, Smart Contracts, and Other Technologies Will Affect the Law', 68 Case W. Res. L. Rev., pp. 747-781

[18] Hildebrandt M. (2007), 'Ambient Intelligence, Criminal Liability and Democracy', 2 Crim. L. E Phil., pp. 163-180

[19] Kowalski A. (1993), 'Artificial Intelligence and Law: A Primer Overview', 51 The Advocate, p. 579

[20] Kuhn T. S (1962), The Structure of Scientific Revolutions, Chicago: University of Chicago Press

[21] Kurzweil R. (2005), The Singularity is Near: When Humans Transcend Biology, New York City: Viking

[22] Lentin J. (2015), Learning Robotics Using Python, Birmingham: Packt publishing

[23] Lessig L. (1999), 'Commentary: The Law of the Horse: What Cyberspace Might Teach Us, 113 Harv. L. Rev., pp. 501-549

[24] Martinez-Miranda J. and Aldea A. (2003), 'Emotions in human and artificial intelligence', 21 Computers in Hum. Behav., pp. 323-341

[25] McLain C. (2017), 'Can Artificial Intelligence Be Conscious?'. Retrieved from https://medium. com/@cameronmclain [accessed 01 Jan 2020]

[26] McMullan T. (2019), “A.I. Judges: The Future of Justice Hangs in the Balance”, Medium, 19 Feb 2019

[27] Nguyễn N., Foulks E. F and Carlin K. (1991), 'Proverbs as Psychological Interpretations among Vietnamese', Asian Folklore Studies, 50(2), New Orleans: Tulane University

[28] Pop A. I. (2006), Criminal Liability of Corporations - Comparative Jurisprudence, Michigan: Michigan State University College of Law

[29] Remus D. and Levy F., 'Can Robots be Lawyers? - Computers, Lawyers, and the Practice of the Law', in ABA Law Practice Division (2016), The Rise of the Machines: Artificial Intelligence and the Future of the Law. Retrieved from https://pdfs.semanticscholar.org/3162/ e236746a99626a4e2a39b3e1b4a006797203.pdf [accessed 01 Jan 2020]

[30] Rieland R. (2018), 'Artificial Intelligence Is Now Used to Predict Crimes. But Is It Biased?'. Retrieved from Smithsonian.com [accessed 01 Jan 2020]

[31] Risse M. (2019), 'Human Rights and Artificial Intelligence: An Urgently Needed Agenda', Human Rights Quarterly 41, pp. 1-16

[32] Sébastien Lafrance (2013), 'La Charte canadienne des droits et libertés à la lumière de la «révolution scientifique» et de la «révolution constitutionnelle» : l'exemple du droit constitutionnel du travail', 18 Lex Electronica 2. Retrieved from https://www.lex-electronica.org/articles/vol18/num2/lacharte-canadienne-des-droits-et-libertes-a-la-lumiere-de-la-revolution-scientifique-et-de-larevolution-constitutionnelle-lexemple-du-droit-constituti/ [accessed 01 Jan 2020]

[33] Susskind R. \& Susskind D. (2015), The Future of the Professions, How Technology Will Transform the Work of Human Expert?, Oxford: Oxford University Press

[34] Susskind R. (2013), Tomorrow's Lawyers: An Introduction to Your Future, Oxford: Oxford University Press

[35] Susskind R. (2010), The End of Lawyers: Rethinking the Nature of Legal Services, Oxford: Oxford University Press

[36] TechCrunch (2017), 'Saudi Arabia bestows citizenship on a robot named Sophia', October 26, 2017 [accessed 8 June 2019]

[37] Weiner K (2018)., 'Can AI Create True Art?', Scientific American, 12 Nov 2018

[38] World Bank (2017), Vietnam. Retrieved from http://data.worldbank.org/country/vietnam [accessed 01 Jan 2020]

[39] Yoon A. H. (2017), 'The Post-Modern Lawyer: Technology and the Democratization of Legal Representation', 66 University of Toronto Law Journal, pp. 456-471

[40] Zhang S., 'Icelandic Has the Best Word for Technology'. Retrieved from https://gizmodo.com/ icelandic-has-the-best-words-for-technology-1702697272 [accessed 01 Jan 2020] 